Eskişehir Osmangazi Üniversitesi IïBF Dergisi

Ağustos 2020, C. 15, S. 2, 437 - 456.

Başvuru : :02.03.2019

Kabul : 04.02.2020

\title{
Kısmi En Küçük Kareler Yapısal Eşitlik Modellemesiyle Bir Elektrik Dağıtım Şirketinin Hizmet Kalitesinin Araştırılması
}

Veysel Yılmaz ${ }^{1}$

Yasemin Kinaş²

Kısmi En Küçük Kareler Yapısal Eşitlik Modellemesiyle Bir Elektrik Dağıtım Şirketinin Hizmet Kalitesinin Araştırılması

Öz

Bu çalışmada, Amerikan Müşteri Memnuniyeti İndeksi (ACSI) Modeliyle bir elektrik dağıtım şirketi müşterilerinin hizmet kalitesi araştırılmıştır. ACSI'de yer alan faktörler Algılanan Kalite, Algılanan Değer, Müşteri Şikâyetleri, Müşteri Beklentileri ve Müşteri Sadakatidir. Çalışmada, faktörler arası ilişkiler ve ACSI modeli, Kısmi En Küçük Kareler Yapısal Eşitlik Modellemesi (KEKK-YEM) yardımıyla test edilmiştir. Bu çalışmada ilk önce anketin tasarlanmasına yönelik literatür taraması yapılmıştır. Daha sonra, geliştirilen anket Eskişehir Büyükdere Mahallesi'nde 400 katılımcıyla yüz yüze görüşülerek uygulanmıştır. Çalışmanın sonunda derlenen veriler yardımıyla, ACSI, KEKK-YEM ile analiz edilmiş ve modelin uygunluğu çeşitli uyum ölçütlerine göre değerlendirilmiştir. Analiz sonuçlarından, Algılanan Kalitedeki bir birimlik artışın, Memnuniyeti 0,25 birim arttıracağı, memnuniyetteki bir birimlik artışın da Sadakati 0,40 birim arttıracağı tahmin edilmiştir.

Anahtar Kelimeler: Elektrik Dağıtım, Amerikan Müşteri Memnuniyeti Modeli (ACSI), Kısmi En Küçük Kareler Yapısal Eşitlik Modellemesi (KEKK-YEM)
Investigation of the Quality of Service of an Electrical Distribution Company with Partial Least Squares Structural Equation Modeling

Abstract

In this study, service quality of customers of an electricity distribution company has been investigated with the American Customer Satisfaction Index Model (ACSI). The factors included in ACSI are Perceived Quality, Perceived Value, Customer Complaints, Customer Expectations and Customer Loyalty. In the study, the relationships between the factors and the ACSI model were tested with the help of Partial Least Squares Structural Equation Modeling (PLSSEM). In this study, a literature review was carried out for the design of the questionnaire. Then, the developed questionnaire was applied face to face with 400 participants in the Büyükdere neighborhood of Eskişehir. At the end of the study, with the help of the data compiled, ACSI was analyzed by PLS-SEM and the suitability of the model was evaluated according to various compliance criteria. From the results of the analysis, it is estimated that a oneunit increase in Perceived Quality will increase the Satisfaction by 0.25 units, and a unit of increase in satisfaction will increase Loyalty by 0.40 units.

Keywords: Electricity distribution, American Customer Satisfaction Index (ACSI), Partial Least Squares Structural Equation Modeling (PLS-SEM)

\section{Giriş}

Teknolojik gelişmelerin hızı elektrik ile çalışan ürünlerin sayısını arttırmış ve buna paralel olarak elektriğe olan talep de artmıştır. Günümüzde elektrik kullanımı zorunlu ihtiyaç haline gelmiş ve müşteri kalite beklentileri de gelişen bu teknoloji ile birlikte aynı oranda artmıştır. Enerji İşleri Genel Müdürlüğü ( EIGM), Türkiye'de enerji kaynaklarının ve tesislerinin envanterini tutmak ve ülkenin her türlü enerji ihtiyacını karşılamak için gerekli planlamaları yapmaktadır. Ayrıca EIGM, enerji kaynaklarının plan ve programlara uygun miktarlarda üretimi ve dağıtımı için gerekli tedbirleri almakta ve alınmasını sağlamaktadır.

Türkiye'de Elektrik Piyasası Kanunu ile istikrarlı bir elektrik piyasasının oluşturulması amaçlanmıştır. Türkiye'de elektriğin üretimi, iletimi, dağıtımı, toptan satışı, perakende satışı, ithali

\footnotetext{
${ }^{1}$ Prof. Dr., Eskişehir Osmangazi Üniversitesi Fen Edb.Fak.İstatistik Bölümü. vyilmaz@ogu.edu.tr, Yazar ORCID bilgisi: https://orcid.org/0000-0001-5147-5047

2 Maden ve Petrol iş̧leri Genel Müdürlüğü, Ankara, yc.yasemincan@gmail.com, Yazar ORCID bilgisi: https://orcid.org/0000-0003-3358-480X
} 
veya ihracı ve bu işlerle ilgili gerçek ve tüzel kişilerin hak ve yükümlülükleri bu kanun kapsamında bulunmaktadır. Bu kanuna ait yürütme işlemleri Enerji Piyasası Düzenleme Kurumu tarafından gerçekleştirilmektedir. Bu kanunlar doğrultusunda 2013 yılında elektrik dağıtım şirketlerinden elektrik tedarik ve satış yetkisi alınmış ve bu yetki elektrik tedarikçilerine verilmiştir. Günümüzde TEDAŞ'ın denetimi altında elektrik dağıtımı; Boğaziçi EDAŞ, Toroslar EDAŞ, Başkent EDAŞ, Dicle EDAŞ, Gediz EDAŞ, İstanbul Anadolu Yakası EDAŞ, Uludağ EDAŞ, Meram EDAŞ, Sakarya EDAŞ, Yeşilırmak EDAŞ, Aydem EDAŞ, Akdeniz EDAŞ, Osmangazi EDAŞ, Aras EDAŞ, Van gölü EDAŞ, Çoruh EDAŞ, Fırat EDAŞ, Adıyaman ve Kahramanmaraş EDAŞ, Çamlıbel EDAŞ, Trakya EDAŞ ve Kayseri ve civarı ETAŞ tarafından yapılmaktadır.

Şehir dağıtım ağlarının bakım, onarım ve işletilmesinden sorumlu olan Elektrik Dağıtım Şirketleri (EDAŞ) için rekabet koşullarının oluşturulması ve geliştirilmesi değerlendirilmektedir. Elektrik piyasasının son düzenlemelerine göre aboneler yüksek hizmet kalitesi sunan elektrik dağıtım şirketlerinden hizmet alabileceklerdir. Bu sayede elektrik piyasasında rekabet koşulları artacak, dolayısıyla dağıtım şirketleri de hizmet kalitelerini müşteri odaklı hale getirmek için daha çok çaba harcamak durumunda kalacaklardır. Ayrıca Enerji ve Tabii Kaynaklar Bakanlığı, elektrik dağıtım şirketleri hizmet kalitesi memnuniyetlerine ilişkin ölçülebilir modeller aracılığıyla çeşitli indeksler geliştirerek bu şirketlerin hizmetlerini izleyebileceği düşünülmektedir. Bu çalışmada EDAŞ'ın sunduğu hizmet kalitesi ölçülerek abonelerin dağıtım şirketi hakkında memnuniyet dereceleri Amerikan Müşteri Memnuniyeti İndeksi (ACSI) Modeli ile araştırılmıştır.

\section{Literatür Taraması}

Literatür taraması yapılarak Amerikan Müşteri Memnuniyeti İndeksi (ACSI) model yapısı, modelin testinde kullanılan yöntemler ve çeşitli hizmet sektörlerinde nasıl kullanıldığı incelenmiştir.

Fornell, Johnson, Michael, Anderson, Cha ve Bryant (1996), ACSI'nın doğasını ve amacını tartışarak modelin altında yatan teoriyi ekonometrik bir yaklaşım ile açıklamıştır. Ayrıca ACSI'nin hem kesitsel hem de zaman içindeki kullanımına ilişkin kıyaslamalar yapmıştır. Bu çaIışmada, yedi büyük ekonomik sektörden toplanan verilerden elde edilen model KEKK-YEM ile tahmin edilmiştir. Çalışmada, müşteri memnuniyeti genellikle sunulan hizmette değil kullanılan ürün için daha yüksek çıkarken, devlet kurumlarında halka sunulan hizmet için müşteri memnuniyeti daha yüksek çıkmıştır.

Johnson, Adreassen, Gustafsson ve Lervik (2001), ulusal hizmet kalitesi ölçen modellerde birkaç değişiklik ve düzeltme önermişlerdir. Bunun için Norveç Müşteri Memnuniyeti Barometresi (NCSB) için yapılan anket verileri KEKK-YEM ile analiz edilmiştir. ACSI ve Avrupa Müşteri Memnuniyet İndeksi (ECSI) modellerinden hareketle faktörlerde bazı değişiklikler yaparak yeni bir model önermişlerdir. Önerilen modelin verileri; bankada, benzin istasyonlarında ve havayolu-tren-otobüs ile seyahat edenlere anket uygulanarak elde edilmiştir. Bulgular, fiyatın sadakat üzerinde doğrudan, memnuniyet üzerinde ise dolaylı etkisi olduğunu göstermiştir. Ayıca duygusal bağımlılığın sadakat üzerinde pozitif etkisi olduğunu göstermişlerdir. Otobüs sektörü hariç diğer sektörler için sadakat memnuniyetten daha önemli çıkmıştır. Bir diğer önemli değişiklik, müşteri beklentileri ile kurumsal imajın değiştirilmesidir. Memnuniyet, her sektördeki kurumsal imaj üzerinde büyük bir etkiye sahiptir. Sonuç olarak müşterilerin güçlü bir kurumsal imaja sahip markaları veya şirketleri tercih ettikleri belirlenmiştir.

Cassel (2001)'e göre, şirketlerin kârında memnun ve sadık müşteriler çok önemli bir rol oynamaktadır. Çalışmada, müşteri memnuniyetini ve sadakatini artırmak için ölçümlerin sağlıklı 
bir şekilde yapılması gerektiği ifade edilmiştir. Cassel (2001); resmi makamlar, sağlık kurumları, huzurevleri, çocuk esirgeme kurumları, okullar tarafından sunulan hizmetlerin yapılan çalışmaların asıl amacı haline geldiğini ifade etmiştir. Bu durumda çalışmaların odak noktası, bu hizmetlerden faydalanan kişilere kaymıştır.

O'Loughlin ve Coenders (2004)'e göre, müşteri memnuniyeti günümüzde rekabet eden kurum/kuruluşlar için kilit nokta haline gelmiştir. Dolayısıyla, birçok araştırmada gelirin bir kısmı tüketici memnuniyetini hem makro (ulusal) hem de mikro (örgütsel) seviyede değerlendirmek için doğru yöntemler geliştirmek için harcanmıştır. Bu çalışmada ulusal Müşteri Memnuniyeti İndeksinin (CSI) hesaplanmasında ML (maksimum likelihood) yöntemi yerine, özellikle çok değişkenli normalliğin sağlanamadığı ve değişken sayısının fazla olduğu karmaşık modellerin olduğu çalışmalarda KEKK-YEM'in kullanılması gerektiği değerlendirilmiştir.

Terblanche (2005), müşteriyi kaybetmenin birçok işletme için büyük bir endişe haline geldiğini ve bunun için de müşteri memnuniyeti ve sadakatini sürekli ölçmek gerektiğini ifade etmiştir. Çalışmada, belirli bir şirket veya marka için müşteriyi elde tutmayı tahmin etmeye yarayacak uygun bir model kullanmasının gerektiği değerlendirilmiştir. Bu makalede, ACSI ve Dönüşüm Modeli (CM) olmak üzere iki önemli model karşılaştırılmıştır. Ankette yer alan katılımcılar, Güney Afrika'nın yedi büyük metropol bölgesinden rastgele çekilen 2.000 tüketiciden oluşmuştur. Katılımcılardan hızlı yemek ve motorlu taşıt endüstrisi ile ilgili olarak ACSI ve CM ölçekleri ile hazırlanan sorulara cevap vermeleri istenmiştir. ACSI modeline göre müşteri sadakati ile müşteri memnuniyeti arasında zayıf bir ilişki olduğu gösterilmiştir.

Song, Li ve Chen (2011) çalışmalarında iki aşamalı bir turist memnuniyeti indeksini test etmeyi amaçlamışlardır. illk olarak, KEKK-YEM ile sektörel düzeyde memnuniyet indeksini tahmin etmiş, ikinci olarak da doğrulayıcı faktör analizi yaparak genel bir turizm memnuniyeti indeksini elde etmişlerdir. Bu çalışmada, Hong Kong'da turizm ile ilgili seçilmiş üç sektöre dayanan pilot bir çalışma yapılmıştır. Sonuçlar, Çinli turistlerin en çok Hong Kong'daki otel sektöründen, ikinci olarak perakende sektöründen ve en az yerel tur operatörlerinden memnun olduklarını göstermiştir. Hong Kong için toplam turist memnuniyeti indeksi 100 üzerinden 74,04 çıkmıştır.

Mutua, Osiolo, Aligula ve Gachanja (2012), Kenya'daki enerji sektöründeki tüketici memnuniyetini analiz ederek hizmet kalitesini değerlendirmiştir. Söz konusu çalışmada KEKK-YEM ile ECSI modeli ile biyokütle, petrol, elektrik ve yenilenebilir enerji sektörlerindeki tüketici memnuniyeti tahmin edilmektedir. Bulgular, tüketici memnuniyetinin en yüksek yenilenebilir enerji sektöründe \% 74,7 ve petrol sektöründe \% 62,8 olduğunu göstermiştir. Elektrik sektörü \% 53,06 ile en düşük tüketici memnuniyetine sahiptir. Ayrıca, halkın bakış açısına göre imajın en yüksek yenilenebilir enerji sektöründe $\% 72,5$ ve petrol sektöründe $\% 63$ olduğunu göstermiştir. Elektrik sektöründe algılanan değer \% 64,2 ile en yüksek orana sahip olmuştur. Çalışmada, bir hizmet tedarikçisinin imajının, tüketicilerin sadakatinin, tüketici beklentilerinin, algılanan değerin, algılanan kalitenin ve şikâyetlerin ele alınma şeklinin tüketici memnuniyetini belirleyen en önemli faktörler olduğu sonucuna varılmıştır.

Grigaliūnaitè ve Pilelienè (2013)'e göre müşteri memnuniyeti, bir kurum/kuruluşun rekabet ortamındaki başarısını belirleyen en önemli faktör olarak kabul edilmektedir. Bu nedenle çalışmada, Litvanya'daki yemek hizmetinin popülaritesinin artması nedeniyle müşteri sadakatinin değerlendirilmesinin gerekliliği ifade edilmiştir. Dolayısıyla araştırmada Litvanya'daki yemek servisleri hakkındaki müşteri memnuniyeti KEKK-YEM ile analiz edilmiştir. Elde edilen bulgulara göre Litvanya'daki yemek servislerinde müşteri beklentileri ve imajın müşteri memnuniyeti üzerinde doğrudan bir etkisi olmadığı, aynı zamanda şikâyetlerin de sadakat üzerinde doğrudan bir 
etkisi olmadığı belirlenmiştir. Ayrıca, Litvanya'daki yemek hizmetleri ile ilgili oluşturulan müşteri memnuniyeti modelinin, bu konu hakkındaki her türlü araştırma için kullanılabileceği düşünülmektedir.

Deng, Yeh ve Sung (2013), uluslararası turizm otellerine yönelik müşteri memnuniyetini tahmin etmek için Otel Müşteri Memnuniyeti İndeksi (H-CSI) modelini ACSI modeliyle birleştirmiştir. Çalışma 412 adet uluslararası otel müşterisi üzerinde gerçekleştirilmiştir. Çalışmada Smart PLS yazılım programı kullanılarak KEKK-YEM yapılmıştır. Araştırma sonuçlarına göre otel yöneticileri genel müşteri memnuniyeti anketi yerine $\mathrm{H}-\mathrm{SCl}$ modelini uygularsa, müşteri memnuniyetini daha iyi yönetmek ve rekabet konusunda avantaj sağlamak için satın alma sonrası müşteri davranışına ilişkin bilgi elde etmenin yanı sıra müşteri memnuniyeti hakkında sağlam bir tahmin elde edebilirler.

Sugiati, Thoyib, Hadiwidjoyo ve Setiawan (2013) algılanan değer, müşteri memnuniyeti ve müşteri sadakati arasındaki ilişkiyi incelemeyi ve açıklamayı amaçlamışlardır. Bu çalışma, Güney Kalimantan'daki Hypermart'ın müşterilerinden 150 katılımcı ile gerçekleştirilmiştir. Verilerin analizinde KEKK-YEM kullanılmıştır. Sonuçlar, algılanan değerin müşteri memnuniyeti üzerinde pozitif etkisi olduğunu göstermiştir. Bu araştırmada dikkat çekici en önemli bulgu, algılanan değerin müşteri sadakati üzerindeki rolünün anlamlı çıkmamasıdır.

Satria, Suzanto ve Sidherta (2015), rekabet ortamında avantaj sağlamak için mobil genişbant tedarikçilerinin sağladıkları hizmet kalitesinin tüketici algılarını belirlediğini ifade etmiştir. Çalışmada, 148 öğrenciyi kapsayan açıklayıcı araştırma yöntemi kullanılmıştır. Bu nedenle veriler, KEKK-YEM kullanılarak analiz edilmiştir. Sonuçlar şikâyetin, müşteri beklentisinin, sadakatin, algılanan kalitenin, müşteri memnuniyetinin ve algılanan değer faktörlerinin tüketici algısının şekillendirilmesinde önemli derecede etkili olduğunu göstermiştir.

Lee, Wang, Lu, Hsieh, Chien, Tsai ve Dong (2016), müşteri memnuniyetini ve sadakatini analiz etmek için Tayvan Müşteri Memnuniyeti İndeksi modelini bir turizm sektörüne uygulamıştır. Çalışma Tayvan'daki bir turizm organizasyonunun hizmet verdiği 242 müşteri üzerinde yapılmıştır. Önerilen araştırma modeli, oldukça karmaşık tahmin modelleri için uygun olan SmartPLS yazılımı kullanılarak KEKK-YEM ile analiz edilmiştir. Sonuçlar, algılanan kalitenin müşteri memnuniyeti üzerinde en büyük etkiye sahip olduğunu göstermiştir.

Pilelienė, Almeida ve Grigaliūnaitè (2016) Litvanya ve Portekiz'in yemek hizmetindeki müşteri memnuniyetini incelemişlerdir. Hazır yemek sektöründe müşteri memnuniyetinin ölçülmesinde düzeltilmiş ECSI uygulanmıştır. Veriler, bu iki ülkedeki yemek endüstrisinde müşteri memnuniyetini etkileyebilecek temel faktörleri belirlemek amacıyla 2014 yılında toplanmıştır. Analiz sonuçlarına göre, yemek hizmetinde müşteri memnuniyetini neyin belirlediği her iki ülkede de oldukça benzer çıkmıştır. Söz konusu analizde, sekiz adet yapısal ilişki önemli bulunmuştur; imaj, beklenti ve sadakati; beklenti, algılanan kaliteyi; algılanan kalite, algılanan değer ve memnuniyeti; algılanan değer memnuniyeti ve memnuniyet sadakat ve şikâyetleri etkilemektedir.

Dülgeroğlu (2017)'na göre fiyatlandırma önemli bir pazarlama aracıdır ve fiyatın tüketici tarafından algılanması pazarlama çıktılarını doğrudan etkilemektedir. Çalışmada, bilimsel literatürdeki çalışmalarda fiyat algısı ortaya konmasına rağmen satın almaya etkisi yeterince analiz edilmediği ifade edilmiştir. Kırklareli'nde yüz yüze anket yöntemi ile veri toplanmıştır. Çalışmada KEKK-YEM analizi ile değer bilinci ve fiyat-kalite ilişkisinin internetten satın almaya etkileri ortaya konmuştur. Analiz sonuçlarına göre değer bilinci ve fiyat-kalite ilişkisi internetten satın alma davranışı ile pozitif ilişki içerisindedir. 
Strenitzerová ve Gan̆a (2018)'e göre hizmet sektöründe müşteri memnuniyetine büyük önem verilmektedir. Çalışmada, hizmet sektöründe faaliyet gösteren şirketlerin kaliteyi yükseltmeleri ve rekabet gücü yüksek bir pazarda müşteri sadakatini sürdürmeleri genel bir endişe haline geldiği ifade edilmiştir. Yazarlar, müşteri memnuniyetinin, müşteri sadakatini etkilediğini belirtmişlerdir. Bu çalışmanın amacı, elektronik iletişim hizmetlerinin kalitesi ile müşteri memnuniyeti konusunda bilgi sağlamak ve Slovak elektronik iletişim pazarında yürütülen ECSI modelinin uygulama sonuçlarını göstermektir. Ayrıca söz konusu çalışmada, ECSı modelinin müşteri sadakati ve müşteri memnuniyeti arasındaki karmaşık ilişkilerin Slovak Telekom tedarikçisinin sürdürülebilirliği üzerindeki etkilerinin daha iyi anlaşılmasının sağlanması amaçlanmıştır.

Ayrıntılı olarak taranan literatürden, ACSı modelinin birçok araştırmacı tarafından çalışıldığı belirlenmiştir. ACSI modeli çeşitli sektör araştırmalarına uyarlanmış ve KEKK-YEM ile analiz edilmiştir. Bu çalışmada ise Elektrik Dağıtım Şirketi'nin hizmet kalitesini ve müşteri memnuniyetini ölçmek için bir anket hazırlanarak söz konusu anket tüm sosyal tabakaların yaşadığı Eskişehir Büyükdere Mahallesinde 30.11.2018 ile 27.12.2018 tarihleri arasında 400 kişiyle yüz yüze görüşülerek yapılmıştır. Veri toplama aracının hazırlanmasında tutuma ilişkin önerilen modelde, müşteri memnuniyeti, sadakat, müşteri şikâyeti, algılanan değer, algılanan kalite ve müşteri beklentileri faktörleri yer almıştır.

\section{Araştırma Yöntemi}

\subsection{Kısmi en küçük kareler yapısal eşitlik modellemesi (KEKK-YEM)}

Kısmi En Küçük Kareler (KEKK) ilk olarak 1982 yılında Wold tarafından ele alınmıştır. Daha sonra Wold, Martens ve Wold (1983) ile Tenenhaus (1998) PLS (KEKK) regresyon modelini ve Lohmöller (1989) ile Tenenhaus, Vinzi, Chatelin ve Lauro (2005) Kısmi En Küçük Kareler Regresyonda Yapısal Eşitlik Modellemesi (KEKK-YEM) yöntemini geliştirmişlerdir. KEKK-YEM gözlenen ve gizil değişkenler arasındaki çok değişkenli karmaşık ilişkilerin modellenmesi için kullanılan istatistiksel bir yaklaşımdır. KEKK-YEM, nedensellik kavramının doğrusal bir şekilde formüle edildiği bileşen tabanlı bir yaklaşımdır. KEKK-YEM diğer istatistiksel analizler ile kıyaslandığında yumuşak bir modelleme tekniği olarak görülmektedir (Fornell ve Bookstein, 1982; Schneeweiss, 1991). Yani, çok değişkenli istatistikte gerekli olan varsayımları (normal dağılıma ilişkin varsayımlar) karşılamanın zor veya imkânsız olduğu durumlarda, KEKK-YEM ile kolay model oluşturulabilmesini ifade etmektedir (Vinzi, Trinchera ve Amato, 2010). Ayrıca örneklem yeterince büyük olduğunda kayıp veri olmasına rağmen KEKK-YEM ile iyi sonuçlar elde edilmektedir (Hair, Hult, Ringle ve Sarstedt, 2013).

KEK-YEM'de herkes tarafından kabul edilen bir uyum iyiliği indeksi yoktur. Bu nedenle model geçerliliği ve uyumu genellikle, faktör yükleri, yol katsayıları, $R^{2}, f^{2}$ ve $Q 2$ istatistikleri kullanılarak değerlendirilmektedir (Kline, 2011).

\subsection{Veri toplama aracı ve örneklem}

Veri derleme aracının tasarlanmasında Mutua vd. (2012)'nin çalışmasından yararlanılmıştır. Çalışmada kullanılan veri derleme aracı demografik bilgiler, Elektrik Dağıtım Şirketi'nin hizmet kalitesini ve müşteri memnuniyetini ölçmek için 3 bölüme ayrılmıştır. Demografik bilgiler kısmında anketi dolduran kişinin cinsiyeti, yaşı, aylık ödediğini ortalama elektrik faturası gibi bilgiler yer almaktadır. Ikinci bölümde tutuma ilişkin ifadeler 1- Hiç Katılmıyorum, 10- Tamamen Katılıyorum şeklinde, üçüncü bölümde ise Elektrik Dağıtım Şirketi'nin sunduğu hizmetlerin değerlendirilmesi için kullanılan ifadeler 1- Çok Düşüktür, 10- Çok Yüksektir şeklinde ölçülmüştür. 
Anket tüm sosyal tabakaların yaşadığı Eskişehir Büyükdere Mahallesinde 30.11.2018 ile 27.12.2018 tarihleri arasında 400 kişiyle yüz yüze görüşülerek yapılmıştır.

Veri toplama aracının hazırlanmasında tutuma ilişkin önerilen modelde, müşteri memnuniyeti, sadakat, müşteri şikâyeti, algılanan değer, algılanan kalite ve müşteri beklentileri faktörleri yer almaktadır. Veri derleme aracının güvenirliğini ve soruların anlaşılabilir olup olmadığını tespit etmek amacıyla anket ile 100 kişiye pilot uygulama yapılmıştır. Analiz sonuçlarında Cronbach Alfa $(\alpha)$ katsayısı 0,96 olarak hesaplanmış ve veri derleme aracının iç tutarlılığı yeterli olarak değerlendirilmiştir.

\subsection{Araştırma Modeli ve Hipotezlerin Tasarımı}

Birçok ülkede müşteri memnuniyetinin ölçülmesi amacıyla çeşitli ölçüm modelleri geliştirilmiştir. Bu ölçüm modellerinin en önemlileri, 1989'da İsveç Müşteri Memnuniyet Barometresi (Swedish Customer Satisfaction Barometer-SCSB), 1992'de Alman Müşteri Barometresi (Deutsche Kunden Barometer-DK), 1994'te Amerikan Müşteri Memnuniyeti Indeksi (American Customer Satisfaction Index-ACSI), 1996'da Norveç Müşteri Memnuniyeti Barometresi (Norwegian Barometer of Customer SatisfactionNCSB), 1998'de İsviçre Müşteri Memnuniyeti Indeksi (Swiss Index of Customer Satisfaction-SWICS) ve 1999'da Avrupa Müşteri Memnuniyeti İndeksidir (European Customer Satisfaction Index-ECSI) (Tüzüntürk, Dülgeroğlu ve Gönüller, 2016).

ACSI, hem pazardaki ürün ve hizmetleri kullanan müşterilerin memnuniyetini ölçmede hem de ölçüm yapılan sektörlerin kendi içinde birbirleriyle kıyaslanmasında kullanılmaktadır. ACSI'nın en önemli özeliklerinden birisi müşterilerin en son deneyiminden ziyade birikime dayalı kaliteye ilişkin bir memnuniyet değerlendirmesini temel almasıdır. Şekil 1'de verilen ACSı modeli, ürün/hizmet kalitesini ve müşteri memnuniyetini anket yöntemi ile ölçülebilecek bir yapıda şekillendirilmiştir. Memnuniyet, anket sorularındaki ölçülebilir değişkenler kullanılarak gizil değişken olarak ölçülür. Belirtilen söz konusu modelde 6 temel değişken yer almaktadır. Bu değişkenler (Bayol, Foye, Tellier ve Tenenhaus, 2000; Tunçay, 2009);

a) Müşteri Beklentileri; müşterinin bir şirketin ürün veya hizmetlerinin kalitesine ilişkin beklentisini ölçer. Müşterilerin hizmet hakkındaki tecrübesi genellikle medya, reklam, satış elemanları ve diğer müşterilerden aldığı bilgilere göre şekillenmektedir. Müşteri beklentileri, ürün veya hizmetin ne kadar iyi performans göstereceği ile ilgili değerlendirmeleri etkiler.

b) Algılanan Kalite; müşterinin son tüketim tecrübesi yoluyla bir şirketin ürün veya hizmetinin kalitesini değerlendirmesinin bir ölçüsüdür. Bir ürünün veya hizmetin müşterinin bireysel ihtiyaçlarını ne derece karşıladığı ve güvenilirlik açısından ne düşündükleri sorulmaktadır.

c) Algılanan Değer; ödenen fiyattan kaliteye ilişkin bir ölçüttür. Müşterilerin satın alma sonrasında mal ve hizmetlerin kalitesine göre fiyatı ve ödenen fiyata göre kalitesi hakkında yaptığı değerlendirmeleri içermektedir.

d) Müşteri Memnuniyeti; müşterilerin edindiği tecrübeye göre satın alma sonrasında mal ve hizmet konusunda ne ölçüde memnun kaldığı, beklentilerini ne ölçüde karşıladığı ve ideal ürün/hizmete ne ölçüde yakın olduğu konusunda yaptığı değerlendirmeleri içermektedir.

e) Müşteri Şikâyeti; bir şirkete belirli bir zaman aralığı içinde bir ürün veya hizmet hakkında doğrudan şikâyette bulunduklarını söyleyen katılımcıların yüzdesi olarak ölçülür. Memnuniyetin müşteri şikâyeti ile negatif bir ilişkisi vardır, müşterilerin memnuniyeti ne kadar fazlaysa o kadar az şikâyet ederler. 
f) Müşteri Sadakati; müşterinin kendisi için başka alternatiflerinde mevcut olduğu bir ortamda, işletmeye, satıcıya ya da ürün veya hizmete yönelik, hissettiği, içten bağlılık ve tesadüfi olmayan alışveriş tutumu, arzusu ve sürekli tercihidir.

Şekil 1. ACSI Araştırma Modeli

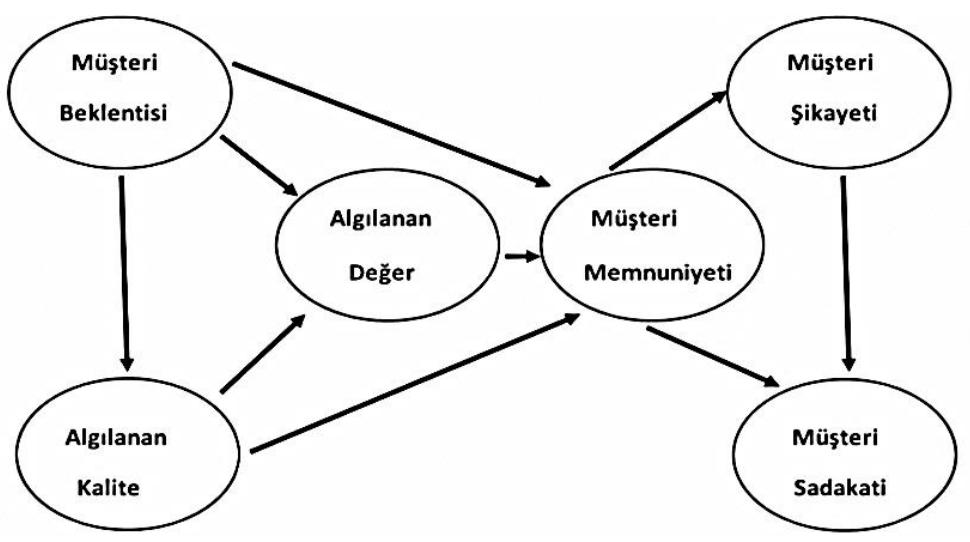

Şekil 1'de yer alan modeldeki ilişkileri sınamak için önerilen hipotezler aşağıda verilmiştir.

Algılanan değer, toplam fayda ve müşterilerin toplam maliyeti ile ilişkilidir. Eskildsen, Kristensen, Juhl ve Ostergaard (2004), algılanan değerin, Danimarka'da perakende ticaretinin müşteri memnuniyetini önemli ölçüde şekillendiren en önemli faktörlerden biri olduğunu belirtmiştir. Terblanche (2005), algılanan değerin, müşteri memnuniyetini önemli ölçüde şekillendiren baskın faktörlerden biri olduğunu ifade etmiştir. Dolayısıyla algılanan değer, müşteri memnuniyetinin bir öncüsüdür. Algılanan değer, algılanan maliyet ile algılanan kalite arasındaki dengeye dayanır. Anderson ve Fornell (2000), Müşteri Memnuniyet İndeksi (CSI) Modelinde algılanan değerin dâhil edilmesinin, sonuçların şirketler ve sektörler arasında karşılaştırma yapılmasını sağladığını belirtmiştir.

\section{H1: Algılanan değerin müşteri memnuniyeti üzerinde pozitif etkisi vardır}

Bayol vd. (2000), Avrupa ülkelerinde bir cep telefonu tedarikçileri için algılanan kalitenin müşteri memnuniyeti üzerinde pozitif etkisi olduğunu göstermiştir. Terblanche (2005), Güney Afrika'daki yedi büyükşehirde fastfood perakende endüstrisinde ACSI modelini kullanarak bir çalışma yapmıştır. Çalışmada algılanan kalite artışının algılanan değeri arttırarak müşteri memnuniyetini arttırdığını ifade edilmiştir.

H2: Algılanan kalitenin algılanan değer üzerinde pozitif etkisi vardır.

H3: Algılanan kalitenin müşteri memnuniyeti üzerinde pozitif etkisi vardır.

Genel olarak, müşteri beklentileri müşterinin hangi tür hizmeti alacağına dair tahminlerdir. Bayol vd. (2000), müşteri memnuniyetinin birçok tahmin ediciden etkilenebileceğini ve müşteri beklentisinin müşteri memnuniyetini pozitif olarak etkilediğini açıklamıştır. Ayrıca, müşteri beklentisinin müşteri memnuniyetinin bir öngörücüsü olarak algılanan kaliteyi oluşturduğu tespit edilmiştir. Van Ryzin, Muzzio, Immerwahr, Gulick ve Martinez (2004), yerel yönetim hizmetlerinde genel memnuniyetin davranışsal sonuçlarını test etmek için ACSı modelini kullanmışlardır. 
Sonuçlar, hizmet kalitesine ilişkin beklentinin kalite algılarını, genel memnuniyeti ve algılanan değeri önemli ölçüde etkilediğini göstermiştir (Deng vd., 2013).

H4: Beklentinin algılanan değer üzerinde pozitif etkisi vardır.

H5: Beklentinin algılanan kalite üzerinde pozitif etkisi vardır.

H6: Beklentinin memnuniyet üzerinde pozitif etkisi vardır.

Maxham ve Netemeyer (2002), müşteri şikâyetlerinin uygun şekilde ele alınmasının müşteri memnuniyetini artırabileceğini ifade etmiştir. Müşteri memnuniyeti ile müşteri şikâyeti arasındaki ilişki tatminsiz müşterilerin davranışlarına bağlıdır. Bir müşteri şikâyetinin etkin bir şekilde ele alınması, müşteri memnuniyetini artırabilir ve şikâyet eden bir müşteriyi sadık bir müşteriye dönüştürebilir (Fornell, 1992). Hirschman (1970)'nın teorisine göre, müşteri memnuniyetinin artmasının müşteri şikayetlerini önemli ölçüde azalttığını göstermiştir (Deng vd., 2013). Bu çaIışmada şikâyet faktörü "S18: EDAŞ’ın müşteri şikâyetlerini ele alma süreci uygundur", "S19: EDAŞ, müşteri şikâyetlerini hızlı çözüme kavuşturur" maddeleri ile ölçülmüştür. Bu nedenle şikâyet faktörü pozitif anlamdadır.

H8: Memnuniyetin şikâyet üzerinde pozitif etkisi vardır.

Sadakat, tekrar satın almayı ifade eder (Jacoby, 1971). Bir otel için, sadık müşteriler, otel hizmetlerini defalarca satın alma eğiliminde olduklarından, en kârlı müşteri türüdür. Ayrıca, sadık müşteriler, ağızdan ağıza reklamın kaynağını temsil etmektedir (Knutson, 1988). Birçok müşteri memnuniyeti çalışması, müşteriyi elde tutma ve önerilerini otelin iş başarısı üzerinde çok önemli bir etki olarak tanımlamıştır (Hallowell, 1996; Kandampully ve Suhartanto, 2000). Sayısız araştırma müşteri memnuniyetini arttırmayı müşteri sadakatini arttırmak için çok önemli bir faktör olarak tanımlamıştır (Barsky, 1992; Smith ve Bolton, 1998; Hallowell, 1996). Araştırmalar, sadık müşterilerin tekrar alımlar yapacağını ve olumlu gelişmeler sağlandığını göstermektedir (Fornell, 1992; Zeithaml, Berry ve Parasuraman, 1996). Bu nedenle, müşteri memnuniyeti, satın alma niyetlerinin (sadakat) oluşumunda kilit nokta olarak kabul edilmektedir. Sonuç olarak, ACSI'de ilişkilerin gösterdiği gibi, müşteri memnuniyeti iyi olduğunda müşteri sadakati artar ve müşteri şikayetleri azalır (Fornell vd., 1996; Deng vd., 2013).

H7: Memnuniyetin sadakat üzerinde pozitif etkisi vardır.

H9: Şikâyetin sadakat üzerinde pozitif etkisi vardır.

\section{Araştırmanın Bulgularının Değerlendirilmesi}

\subsection{Tanımlayıcı istatistikler}

Katılımcıların 183'ü kadın (\%46), 217'si erkektir (\%54). Katılımcıların \%25'i 18-24 yaş aralığında, \%32'si 25-34 yaş aralığında, \%25'i 35-44 yaş aralığında, \%13'ü 45-59 yaş aralığında, \%5'i ise 60 yaş ve daha fazladır. "EDAŞ (Elektrik Dağıtım Şirketi) Aboneliğiniz" sorusuna katılımcılardan 79'u Abone Değilim, 282'si Konut Abonesiyim, 31'i İşyeri Abonesiyim, 8'i de Hem Konut Hem İ̧yeri Abonesiyim cevabını vermiştir. Katılımcıların en çok \%70,5’i Konut Abonesiyim cevabını vermiştir.

“Elektrik Kesintisi Olacağından En Sık Haberdar Olduğunuz Haber Kaynağı Hangisidir?" sorusuna katılımcıların 8'i SMS, 42'si Sosyal Ağ (EDAŞ resmi sitesi, facebook, twitter, e-mail), 7'si Gazete, TV, 10'u Çağrı Merkezi, 92'si Arkadaş, Komşu veya Diğer Kişilerden, 241'si ise Haberdar Olmuyorum yanıtını vermişlerdir. Katılımcıların en çok \%60,3'ü haberdar olmadığını belirtmişlerdir. "Son Bir Ay İçinde Kaç Kez Elektrik Kesintisi Olmuştur?" sorusuna katılımcıların 61'i Hiç Kesilmedi, 221'i Bir, 6'sı Her Gün, 25'i Haftada 1, 58'i Haftada 2 ve Daha Fazla, 29'u ise 15 Günde 
1 cevabını vermiştir. Katılımcıların en çok \%55,3'ü son bir ay içinde 1 kez kesinti olduğu cevabını vermişlerdir.

"Yaşanılan Elektrik Kesintilerinin Ortalama Süresi Ne Kadardır?" sorusuna katılımcıların 103'ü 1 Saatten Az, 219'u 1-2 Saat, 40'ו 2-3 Saat, 9'u 3 Saatten Fazla, 29'u ise Bilemiyorum cevabını vermiştir. Katılımcıların en çok oranla \%54,8'i kesintilerin ortalama 1-2 saat sürdüğünü ifade etmişlerdir. "Konut için Aylık Ödediğiniz Elektrik Faturası Ortalama Ne Kadardır?" sorusuna katılımcıların 38'i 50 TL'den az, 124'ü 50-79 TL, 114'ü 80-109 TL, 75'i 110-139 TL, 38'i 140169 TL, 11'si 170 TL'den Fazla cevabını vermiştir. Katılımcıların en çok oranla \%31'inin aylık ödediği ortalama elektrik faturalarının 50-79 TL olduğu tespit edilmiştir.

\subsection{Veri Analizi}

Bu çalışmada verilerin KEKK-YEM yöntemi ile analiz edilmesinde SmartPLS 3.0 paket programının kullanılmıştır. İlk önce ölçüm modelinin uyumu, daha sonra da yapısal modelin uyumu ve hipotez testi sonuçları değerlendirilmiştir.

\subsection{1. Ölçüm Modelin Geçerliliği}

Yakınsaklık Geçerliliğinin (Convergent validity) sağlanabilmesi için genellikle üç ölçüt kullanılır. Birincisi, gizil değişkenlere ait gözlenen değişkenlerin standartlaştırılmış faktör yükünün 0,50'den büyük ve istatistiksel olarak anlamlı olması gerekmektedir (Fornell ve Larcker, 1981). İkincisi, her bir yapı için Yapı Güvenilirliği (Composite Reliability-CR) ve Cronbach Alfa (CA) değerinin 0,70'den büyük olması gerekmektedir (Hair, Anderson, Tatham ve Black, 1998). Üçüncüsü, her gizil değişkenin Ortalama Açıklanan Varyans (Average Variance Extracted-AVE) değerinin 0,50'den yüksek olması gerekmektedir (Fornell ve Larcker, 1981). Ayrıca, ilgili faktörün CR değerlerinin 0,60'dan büyük olduğu durumlarda, AVE'nin 0,50'den küçük olmasının kabul edilebilir olduğunu ve yapı geçerliliğinin yeterli olduğunu ifade edilmiştir (Hair vd., 1998). Tablo 1 'de CA, CR ve AVE değerleri topluca verilmiştir.

Çalışmanın yapı güvenilirliği kontrol edildiğinde $C R$ değerlerinin $A=0,79 ; B=0,93 ; C=0,92$; $D=0.91 ; E=0,90 ; F=0,92$ olduğu ve $A V E$ değerlerinin 0,65 'ten büyük olduğu gözlenmiştir.

Tablo 1: Cronbach Alfa, CR ve AVE Değerleri

\begin{tabular}{cccc}
\hline Faktörler & $\begin{array}{c}\text { Cronbach } \\
\text { Alfa }\end{array}$ & Yapı Güvenirliği (CR) & Ortalama Açıllanan Varyans (AVE) \\
\hline A & 0,65 & 0,79 & 0,65 \\
B & 0,91 & 0,93 & 0,73 \\
C & 0,89 & 0,92 & 0,75 \\
D & 0,89 & 0,91 & 0,78 \\
E & 0,83 & 0,90 & 0,75 \\
F & 0,83 & 0,92 & 0,86 \\
\hline
\end{tabular}

Ölçüm modelinin ayırt edici geçerliliğinin (Discriminant validity) her bir yapının AVE değerinin karekökünün, o yapı ile diğer yapılar arasındaki korelasyonunun karşılaştırılmasıyla kontrol edilir. Bu karşılaştırmalar sonucunda AVE'nin karekök değerleri daha büyük ise ayırt edici geçerlilik sağlanmış olur (Fornell ve Larcker, 1981). Tablo 2'de ele alınan modelin ayırt edici geçerlilik değerleri verilmiştir. 
Tablo 2: Ayırt Edici Geçerlilik

\begin{tabular}{ccccccc}
\hline & $A$ & $B$ & $C$ & $D$ & $E$ & $F$ \\
\hline$A$ & $\mathbf{0 . 8 1}$ & & & & & \\
$B$ & 0.69 & $\mathbf{0 . 8 6}$ & & & & \\
$C$ & 0.65 & 0.79 & 0.87 & & & \\
$D$ & 0.62 & 0.71 & 0.74 & 0.88 & 0.87 & 0.93 \\
$E$ & 0.62 & 0.62 & 0.62 & 0.74 & 0.75 & 0,86 \\
$F$ & 0.56 & 0.61 & 0.66 & 0.76 & $\mathbf{0 , 7 5}$ & \\
AVE & $\mathbf{0 . 6 5}$ & $\mathbf{0 . 7 3}$ & $\mathbf{0 . 7 5}$ & $\mathbf{0 , 7 8}$ & \\
\hline
\end{tabular}

NOT: Tablo 2'de köşegen elemanları AVE'nin kare kökü, köşegen dışında kalan elemanlar ise gizil değişkenler arasındaki korelasyon katsayılarıdır.

\subsubsection{Yapısal Modelin Değerlendirilmesi}

\subsubsection{Uyum Ölçütleri}

Ölçüm modelinin geçerliliği ve güvenilirliği doğrulandıktan sonra yapısal model değerlendirilir. Yapısal model genellikle, belirlilik katsayısı $R^{2}$, etki büyüklüğü $f^{2}$, yol katsayısı ve t-değeri, tahmin edicinin geçerliliği $Q^{2}$ ve uyum iyiliği (The goodness-of-fit index -GoF) değerlendirilir. Ayrıca modelin uyumu için Smart PLS 3 yazılımının hesapladığı ölçüler Standartlaştırılmış Hata Kareler Ortalamasının Karekökü (Standardized Root Mean Square Residual SRMR), Karesel Öklidyen Uzaklık (The Squared Euclidean distance-d_ULS), Geodesic Uzaklık (The Geodesic Distance-d_G), Ki-Kare ve Normlandırılmış Uyum İndeksi (Normed Fit Index -NFI) değerleri kullanilır.

$\mathrm{R}^{2}$ değerlerinin büyüklüğü tahmin değerlerinin doğruluğunun belirlenmesinde önemlidir. Buna bağlı olarak araştırmacılar $Q^{2}$ değerini de incelemektedir. $Q^{2}$ ölçüsü modelin tahminin geçerliliğinin bir göstergesidir. Yapısal modelinin $Q^{2}$ değerinin sıfırdan büyük olması, tahmin geçerliliğini sağladığını gösterir (Chin, 1998). $Q^{2}$ değerleri $A=0,30 ; B=0,43 ; D=0,43 ; E=0,43$ ve $F=0,48$. Yapılan analiz sonucunda elde edilen $Q^{2}$ değerlerine göre model geçerliliği sağlanmıştır. Yani söz konusu model orijinal gözlenen değişkenleri iyi bir şekilde tahmin etmektedir.

$f^{2}$ (effect size), tüm içsel gizil değişkenlerin $R^{2}$ değerlerinin değerlendirilmesine ek olarak, belirli bir dışsal gizil değişkenin modelden çıkarıldığında, $R^{2}$ değerindeki değişim, bu çıkarılan yapının içsel gizil değişkenler üzerinde önemli bir etkiye sahip olup olmadığını değerlendirmek için kullanılır. Etki ölçüsü $\mathrm{f}^{2}$ tahmin edici, bir gizil değişkenin yapısal düzeyde zayıf $\quad(0,02<$ $\left.f^{2}<0,14\right)$, orta $\left(0,15<f^{2}<0,34\right)$ ve yüksek $\left(f^{2}>0,34\right)$ düzeyde bir etkiye sahip olduğunu ifade etmektedir (Cohen, 1988). Analiz sonucu elde edilen $\mathrm{f}^{2}$ değerlerine göre: $\mathrm{C}$ dışsal gizil değişkeni; $B(1,71)$ yüksek, $D(0,17)$ orta ve $A(0,06)$ zayıf düzeyde etkilemektedir.

KEKK-YEM'de genel bir uyum indeksi olmadığı gibi Tenenhaus vd. (2004) tarafından uyum iyiliği ölçütü olarak uyum iyiliği indeksi (GoF) önerilmiştir. GoF indeksi hem ölçüm modeli hem de yapısal modelin performansını belirlemek ve bütün modelin tahmin performansı için standart bir ölçüm sağlamak için geliştirilmiştir. GOF indeksi, 0 ile 1 arasında değerler alır. GoF indeksinin uyum dereceleri GoF $<0,10$ (az), 0,10<GoF $<0,25$ (orta), 0,25<GoF $<0,36$ (iyi) GoF $>0,36$ (çok iyi) şeklindedir (Wetzels vd., 2009). GoF indeksi, gizil değişkenler için elde edilen AVE ile $\mathrm{R}^{2}$ değerlerinin ortalamalarının çarpımının karekökünün alınması ile elde edilir.

GoF $=\sqrt{\text { Ortalama }\left(R^{2}\right) \times \text { Ortalama }(A V E)}$

$\mathrm{R}^{2}$ değerlerinin ortalaması 0,59 ve AVE değerlerinin ortalaması 0,75 olmak üzere GoF indeksi 0,66 olarak bulunmuştur. Bu sonuç modelin çok iyi uyumu sahip olduğunu göstermektedir. 
d_ULS ve d_G sırasıyla öklid uzaklığının karesi ve iki nokta arasındaki en kısa uzaklığın karesi olarak tanımlanmaktadır. d_ULS ve d_G tam uyum kriterleri model hakkında bir değerlendirme yapmak için kullanılan kullanılan istatistiklerdir. SmartPLS'de yapılan Bootstrap analizinin sonucunun değerlendirilmesinde kullanılmaktadır. Modelin iyi uyum sağlaması için güven aralığının üst sınırı, d_ULS ve d_G tam uyum kriterlerinin orijinal değerinden daha büyük olması gereklidir. Bu nedenle güven aralığının üst sınırı \% 95 veya \% 99 olarak seçilir. Modelin korelasyon matrisi ile ampirik korelasyon matrisi arasındaki fark istatistiksel olarak anlamsız $(p>0,05)$ olduğunda modelin uygun olduğu ifade edilir. Aksi takdirde, model uyumu belirlenememektedir(https://www.smartpls.com/documentation/algorithms-and-techniques/model-fit-16-122019).

Modelin kabul edilebilir uyuma sahip olması için SRMR değerinin 0,10'den küçük bir değer alması istenir. Model için SRMR değeri 0.075 olarak hesaplanmıştır. d_ULS ve d_G tam uyum kriterleri için hesaplanan 1,072 ile 0,925 değerleri ise $p>0,05$ çıkmıştır. Ki-kare değeri ise 493.690 çıkmıştır. NFI değerinin ise 0 ie 1 arasında değerler alması istenir. NFI 'nın 1'e yakın değer alması modelin iyi uyuma sahip olduğunu göstermektedir. Çalışmadaki model için NFI 0,071 olarak hesaplanmıştır.

Modelin değerlendirilmesinde son olarak da gizil değişkenler arasında çoklu iç ilişki (collinearity) olup olmadığı belirlenmelidir. Bunun için VIF (variance inflation factor- varyans şişkinlik faktörü) değerleri incelenir. VIF değerinin 5'den küçük olması değişkenler arasında eş doğrusallık olmadığını göstermektedir (Hair vd., 2011). SmartPLS 3.0 yazılımından elde edilen gizil değişkenler arasındaki VIF değerleri Tablo 3'de verilmiştir. Hesaplanan VIF değerlerine bakıldığında bütün değerlerin 5’ten küçük olduğu görülmektedir. Buna göre gizil değişkenler arasında çoklu iç ilişki problemi olmadığı söylenebilir.

Tablo 3. Gizil Değişkenler İ̧̧in VIF Değerleri

\begin{tabular}{ccccccc}
\hline & A & B & C & D & E & F \\
\hline A & & & & 2,03 & & \\
B & 2,87 & & 3,40 & & \\
C & 2,87 & 1,00 & & 2,95 & & 1,00 \\
D & & & & 2,84 & \\
E & & & & 2,84 & \\
F & & & & & & \\
\hline
\end{tabular}

\subsubsection{Yol Katsayıları ve Hipotez Testi}

SmartPLS 3.0 hazır yazılımı kullanılarak Şekil 2'de yer alan model elde edilmiştir. Analiz sonuçlarına göre, beklenti dışsal (egzojen) gizil değişkeni ile algılanan kalite içsel (endojen) gizil değişkeni arasında pozitif yönde istatistiksel olarak anlamlı bir ilişki bulunmuştur. Bu değer, beklentideki bir puanlık artışın algılanan kalitede 0,79 puanlık artışa neden olacağını ifade etmektedir.

Beklenti dışsal gizil değişkeni ile algılanan değer gizil değişkeni arasında pozitif yönde anlamlı bir ilişki bulunmuştur. Bu değer beklentideki bir puan artışın algılanan değerde 0,28 puanlık artışa neden olacağını ifade etmektedir. Beklenti dışsal gizil değişkeni ile memnuniyet içsel gizil değişkeni arasında istatistiksel olarak anlamlı bir ilişki bulunmuştur. Bu değer beklentideki bir puanlık artışın memnuniyette 0,43 puanlık artışa neden olacağını ifade etmektedir. 
Algılanan kalite ile algılanan değer arasında pozitif yönde anlamlı bir ilişki bulunmuştur. Bu değer, algılanan kalitedeki bir puan artışın algılanan değerde 0,47 puanlık artışa neden olacağını ifade etmektedir. Algılanan kalite ile memnuniyet gizil değişkeni arasında pozitif yönde istatistiksel olarak anlamlı bir ilişkinin olduğu görülmektedir. Algılanan kalitedeki bir puanlık artış memnuniyette $0.25^{\prime}$ lük bir artışa neden olmaktadır. Algılanan değerdeki bir puanlık artış memnuniyet gizil değişkeninde $0.17^{\prime}$ lik artış neden olmaktadır. Memnuniyet ve sadakat gizil değişkenleri arasında pozitif yönde istatistiksel olarak anlamlı bir ilişki bulunmuştur. Bu değer memnuniyetteki bir puanlık artışın sadakatteki 0,40 puanlık artışa neden olacağını göstermektedir.

Çalışmada şikâyet faktörü, "EDAŞ”ın müşteri şikâyetlerini ele alma süreci uygundur" ve "EDAŞ, müşteri şikâyetlerini hızlı çözüme kavuşturur" şeklinde pozitif olarak tanımlanmıştır. Bu nedenle memnuniyet ile şikâyet arasındaki $(0,76)$ ve şikâyet ile sadakat arasındaki $(0,44)$ ilişki katsayısı pozitif olarak hesaplanmıştır.

\section{Şekil 2. Modelin Ayrıntılı KEKK-YEM Diyagramı}

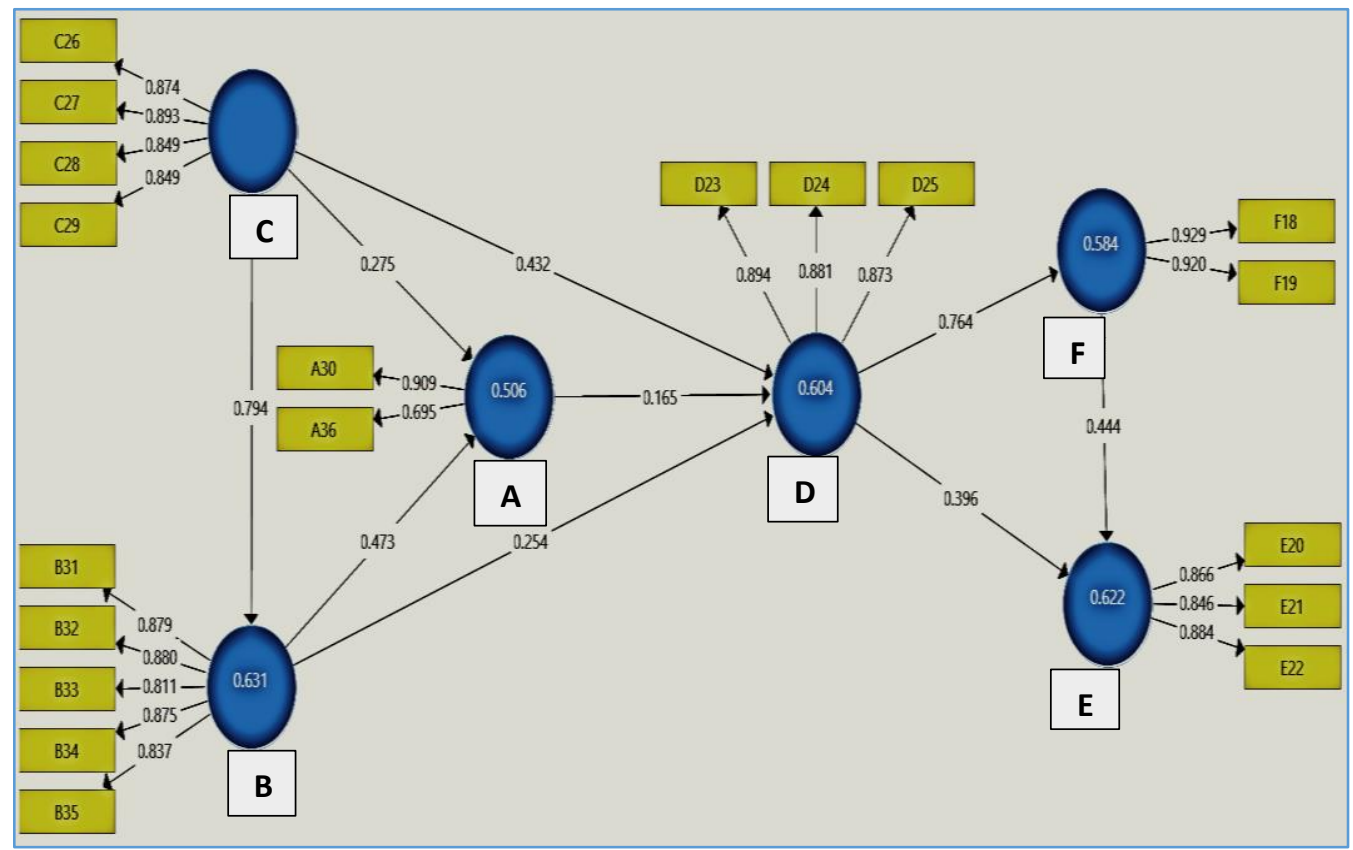

A: Algılanan Değer B: Algılanan Kalite C: Beklenti D: Memnuniyet E: Sadakat F: Şikâyet

Tablo 4'te standartlaştırılmış faktör yükleri, t ve $R^{2}$ değerleri verilmiştir. $A, B, D, E$ ve $F$ gizil değişkenleri için $R^{2}$ değerleri sırasıyla $0,51,0,63,0,60,0,62$ ve 0,58 olarak hesaplanmıştır. Faktör yüklerinin anlamlılığına ilişkin $\mathrm{t}$ değerleri incelendiğinde tüm faktör yüklerinin istatistiksel olarak anlamlı olduğu görülmektedir. 
Ağustos 2020, C. 15, S. 2

Tablo 4. Standartlaştırılmış Faktör Yükleri, $t$ ve $R^{2}$ Değerleri

\begin{tabular}{|c|c|c|c|}
\hline & & Standart & \\
\hline Faktörler & Maddeler & Yükler & t-Değer \\
\hline \multirow{2}{*}{$\begin{array}{l}\text { Algılanan Değer }(\boldsymbol{A}) \\
C R=0,79: \text { AVE }=0,65 \\
R^{2}=0,51\end{array}$} & $\begin{array}{l}\text { S30: EDAŞ'ın hizmetleri için ödediğim ücretleri dü- } \\
\text { şündüğümde, sunulan hizmetlerin kalitesi, }\end{array}$ & 0,91 & 38,33 \\
\hline & $\begin{array}{l}\text { S36: EDAŞ'ın bana sağlamış olduğu hizmetlerin kali- } \\
\text { tesini göz önünde bulundurduğumda, ödediğim üc- } \\
\text { ret, }\end{array}$ & 0,70 & 6,61 \\
\hline \multirow{5}{*}{$\begin{array}{l}\text { Algılanan Kalite }(B) \\
C R=0,93: A V E=0,73 \\
R^{2}=0,63\end{array}$} & $\begin{array}{l}\text { S31: EDAŞ’ın elektrik şebekesinin teknik kalite dü- } \\
\text { zeyi, }\end{array}$ & 0,88 & 39,17 \\
\hline & S32: EDAŞ’tan aldığım hizmetin genel kalite düzeyi, & 0,88 & 42,52 \\
\hline & $\begin{array}{l}\text { S33: Herhangi bir sorunla karşılaştığımda, EDAŞ’ın } \\
\text { soruna çözüm bulmadaki hızı, }\end{array}$ & 0,81 & 22,47 \\
\hline & $\begin{array}{l}\text { S34: Müşteri olarak taleplerime sağlanan çözümlerin } \\
\text { uygunluğu ve yararlılığı, }\end{array}$ & 0,88 & 32,10 \\
\hline & $\begin{array}{l}\text { S35: EDAŞ’ın beni bilgilendirmesindeki netliği ve şef- } \\
\text { faflığı, }\end{array}$ & 0,84 & 27,30 \\
\hline \multirow[t]{4}{*}{$\begin{array}{l}\text { Beklenti }(C) \\
C R=0,92: A V E=0,75\end{array}$} & $\begin{array}{l}\text { S26: EDAŞ’ın hizmetlerinde problem yaşarsam, bunu } \\
\text { işletmenin telafi edeceğine ilişkin beklentim, }\end{array}$ & 0,87 & 29,10 \\
\hline & $\begin{array}{l}\text { S27: Herhangi bir elektrik kesintisi problemi yaşar- } \\
\text { sam, bunun en kısa sürede çözüme ulaştırılacağına } \\
\text { ilişsin beklentim, }\end{array}$ & 0,89 & 43,93 \\
\hline & $\begin{array}{l}\text { S28: İkamet ettiğim semtte planlı bir elektrik kesinti- } \\
\text { sinde, EDAŞ'ın beni önceden bilgilendireceğine ilişkin } \\
\text { beklentim, }\end{array}$ & 0,85 & 27,15 \\
\hline & $\begin{array}{l}\text { S29: İkamet ettiğim semtte planlı bir elektrik kesinti- } \\
\text { sinde, EEDAŞ’ın beni önceden bilgilendireceğine iliş- } \\
\text { kin beklentim, }\end{array}$ & 0,85 & 36,43 \\
\hline \multirow{3}{*}{$\begin{array}{l}\text { Memnuniyet }(D) \\
C R=0,91: A V E=0,78 \\
R^{2}=0,60\end{array}$} & S23: EDAŞ'tan aldığım hizmetten memnunum. & 0.89 & 35,03 \\
\hline & S24: EDAŞ, beklediğim tüm hizmetleri karşılıyor. & 0.88 & 20,43 \\
\hline & $\begin{array}{l}\text { S25: EDAŞ'ın arızalara zamanında müdahalesi beni } \\
\text { tatmin ediyor. }\end{array}$ & 0.87 & 20,02 \\
\hline \multirow{4}{*}{$\begin{array}{l}\text { Sadakat }(\text { E) } \\
C R=0,90: A V E=0,75 \\
R^{2}=0,62\end{array}$} & S20: Elektrik dağıtım şirketi seçmem gerekirse, yine & 707 & 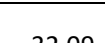 \\
\hline & EDAŞ’ı seçerdim. & 0.87 & 32,09 \\
\hline & $\begin{array}{l}\text { S21: EDAŞ’ın hizmetlerini, yakın çevreme takdir etti- } \\
\text { ğimi anlatıyorum. }\end{array}$ & 0.85 & 23,69 \\
\hline & $\begin{array}{l}\text { S22: EDAŞ’ın elektrik hizmetleri eksik olsa bile, yine } \\
\text { de başka bir elektrik dağıtım şirketini seçmem. }\end{array}$ & 0.88 & 2,83 \\
\hline \multirow{2}{*}{$\begin{array}{l}\text { Sikayet (F) } \\
C R=0,92: A V \\
R^{2}=0,58\end{array}$} & $\begin{array}{l}\text { S18: EDAŞ’ın müşteri şikâyetlerini ele alma süreci uy- } \\
\text { gundur. }\end{array}$ & 0,93 & 77,04 \\
\hline & $\begin{array}{l}\text { S19: EDAŞ, müşteri şikâyetlerini hızlı çözüme kavuş- } \\
\text { turur. }\end{array}$ & 0,92 & 51,01 \\
\hline
\end{tabular}


Standartlaştırılmış parametre tahminleri, t değerleri ve hipotez testi sonuçları Tablo 5 'te yer almaktadır. Tablo 5'teki sonuçlara göre hipotezlerin tamamının desteklendiği görülmüştür.

Tablo 5. Standartlaştırılmış Parametre Tahminleri ve Hipotez Testi Sonuçları

\begin{tabular}{|c|c|c|c|c|}
\hline Hipotez & ilişki & $\begin{array}{c}\text { Standartlaştırılmış parametre } \\
\text { tahminleri }\end{array}$ & t -değeri & $\begin{array}{l}\text { Hipotez So- } \\
\text { nucu }\end{array}$ \\
\hline $\mathrm{H}_{1}$ & $A \rightarrow D$ & 0,17 & $2,00^{*}$ & Desteklendi \\
\hline $\mathrm{H}_{2}$ & $B \rightarrow A$ & 0,47 & $5,14^{* *}$ & Desteklendi \\
\hline $\mathrm{H}_{3}$ & $B \rightarrow D$ & 0,25 & $2,14^{*}$ & Desteklendi \\
\hline $\mathrm{H}_{4}$ & $C \rightarrow A$ & 0,28 & $3,07 * *$ & Desteklendi \\
\hline $\mathrm{H}_{5}$ & $C \rightarrow B$ & 0,79 & $15,07^{* *}$ & Desteklendi \\
\hline $\mathrm{H}_{6}$ & $C \rightarrow D$ & 0,43 & $3,42 * *$ & Desteklendi \\
\hline $\mathrm{H}_{7}$ & $\mathrm{D} \rightarrow \mathrm{E}$ & 0,40 & $5,15^{* *}$ & Desteklendi \\
\hline $\mathrm{H}_{8}$ & $D \rightarrow F$ & 0,76 & $17,71^{* *}$ & Desteklendi \\
\hline $\mathrm{H}_{9}$ & $\mathrm{~F} \rightarrow \mathrm{E}$ & 0,44 & $5,44 * *$ & Desteklendi \\
\hline
\end{tabular}

${ }^{*} \mathrm{p}<0,05 ;{ }^{*} \mathrm{p}<0,01$

\section{Sonuç}

Çalışmada bir elektrik dağıtım şirketinin hizmet ölçümüne ilişkin tutumlar ACSı modeli temel alınarak KEKK-YEM yöntemi ile analiz edilmiştir. ACSI modelinde müşteri memnuniyeti, algılanan değer, sadakat, algılanan kalite, müşteri şikâyeti, müşteri beklentisi faktörleri değerlendirilmektedir. Beklenti dışsal gizil değişkeni ile algılanan kalite içsel gizil değişkeni arasında pozitif yönde istatistiksel olarak anlamlı bir ilişki bulunmuştur. Bu sonuç, abonelerin beklentileri karşılandıkça dağıtım şirketine yönelik algılanan kalite düzeyinin arttığı anlamına gelir. Beklenti dışsal gizil değişkeni ile algılanan değer içsel gizil değişkeni arasında pozitif yönde istatistiksel olarak anlamlı bir ilişki bulunmuştur. Bu bulgu, abonelerin beklentileri karşılandıkça hizmetler için ödenen ücretler ile algılanan hizmetlerin kalitesi arasında bir dengenin oluşacağı anlamını taşır. Beklenti dışsal gizil değişkeni ile memnuniyet içsel gizil değişkeni arasında pozitif yönde istatistiksel olarak anlamlı bir ilişki bulunmuştur. Yani, abonelerin beklentileri karşılandıkça elektrik dağıtım şirketine olan memnuniyet seviyelerinin arttığı sonucuna ulaşılmıştır.

Algılanan kalite ile algılanan değer arasında pozitif yönde istatistiksel olarak anlamlı bir ilişki bulunmuştur. Yani, abonelerin aldıkları hizmetin ihtiyaçlarını karşılaması ve güven duymaları halinde hizmet için ödedikleri ücret konusundaki değerlendirmeleri olumlu olacaktır. Algılanan kalite ile memnuniyet gizil değişkeni arasında pozitif yönde istatistiksel olarak anlamlı bir ilişki bulunmuştur. Buna göre, tüketim tecrübeleri ne kadar iyiyse memnuniyetlerinin de pozitif olarak etkileneceği yorumu yapılabilir. Algılanan değer ve memnuniyet gizil değişkenleri arasında pozitif yönde istatistiksel olarak anlamlı bir ilişki bulunmuştur. Abonelerin aldıkları hizmetin ihtiyaçlarını karşılaması ve güven duymaları halinde şirkete duydukları memnuniyet seviyeleri de artacaktır.

Memnuniyet ile şikâyet gizil değişkenleri arasında pozitif yönde istatistiksel olarak anlamlı bir ilişki bulunmuştur. Bu bulgu, elektrik dağıtım şirketlerinin hizmetlerine yönelik memnuniyet arttıkça, katılımcıların şikâyetlerinin kolayca çözümlenebileceğine yönelik inançlarının güçleneceği anlamına gelir. Memnuniyet ve sadakat gizil değişkenleri arasında pozitif yönde istatistiksel olarak anlamlı bir ilişki bulunmuştur. Elektrik dağıtım şirketlerinin hizmetlerine yönelik memnuniyet arttıkça ilgili şirkete duydukları bağlılıklarının da arttığı anlamına gelir. Şikâyet ile sadakat 
gizil değişkenleri arasında pozitif yönde istatistiksel olarak anlamlı bir ilişki bulunmuştur. Bu sonuç, katılımcıların şikâyetlerinin kolayca çözümlenebileceğine yönelik inançlarındaki artış dağıtım şirketlerine olan bağlılıkları artacaktır.

Literatüre bakıldığında, birçok yazar tarafından müşteri memnuniyetini ölçmek için ACSı modeli uygulanmış ve KEKK-YEM ile analiz edilmiştir. Söz konusu ACSI modeli genellikle turizm, yemek, ulaşım sektörlerinde uygulanmıştır. Bu çalışmada ise elektrik dağıtım şirketlerinin hizmet ölçümüne ilişkin müşteri memnuniyeti araştırılmıştır. Terblanche (2005), CFI Group (2013) ve Fornell (1996)'in çalışmalarında, bu çalışma ile benzer olarak KEKK-YEM analiz yöntemi kullanılarak ACSI modeli oluşturulmuştur. Hipotezler benzer şekillerde kurularak test edilmiştir. Fornell vd. (1996), müşteri memnuniyetinin, değer ya da fiyat odaklı olmaktan ziyade kaliteden kaynaklandığını değerlendirmiştir. Terblanche (2005)'ın çalışmasında, ACSI modelinin müşteri sadakatini öngörmek için ürettiği sonuçlar, müşteri sadakati ile müşteri memnuniyeti arasında zayıf bir ilişki olduğunu göstermektedir. Bu bulgular, müşteri memnuniyetinin müşteri sadakatinin tek öngörüsü olamayacağını belirten çeşitli yazarların görüşleri ile uyumludur. CFI Group (2013) ise 70 yıllık sosyal psikoloji araştırmasından edindiği bilgiye dayanarak, bir müşterinin bir ürün/hizmet deneyimi hakkındaki düşüncesini; ürün/hizmet deneyiminin farklı yönlerine göre performans algıları, tutumları ve ürün/hizmete ilişkin gelecekteki davranışsal niyetlerine göre ölçtüğünü değerlendirmiştir.

EDAŞ abonelerinin ilgili şirketten ne derece memnun olduklarını ölçmek için yapılan ACSI memnuniyet skoru $46 \%$ olarak hesaplanmıştır. Bu sonuç memnuniyetin ortalamanın altında kaldığını göstermektedir. Müşteri memnuniyeti odaklı bir işletme, sunduğu hizmetlerde yenilikler yaparak müşterilerin beklentilerini karşılamaya çalışmalıdır. Bu doğrultuda daha kaliteli hizmet verebilmek adına elektrik dağıtım şirketleri abonelerinin, şikâyet ve taleplerini dikkate alarak memnuniyetlerini sağlayabilmeyi hedeflemelidir. Çalışmada, tüm elektrik dağıtım şirketleri için hizmet kalite memnuniyet indeksinin ayrı ayrı hesaplanıp bir indeksin geliştirilmesinin gerekliliği değerlendirilmektedir. Ayrıca bu indeks hesabının en az 6 ayda bir hesaplanması ve Enerji ve Tabii Kaynaklar Bakanlığınca izlenmesi önerilmektedir. Abonelerin elektrik dağıtım şirketlerini serbest piyasadan seçebilme imkânları genişletilerek rekabet piyasasının geliştirilmesinin yararlı olabileceği dikkate alınmalıdır.

Bu çalışmadaki anket, 2018 Kasım-Aralık aylarında katılımcılarla yüz yüze görüşmeyle yapıldığı için hava koşulları nedeniyle bazı zorluklar yaşanmıştır. Ayrıca, sadece bir şehrin bir mahallesinin ele alınması çalışmanın kısıtını oluşturmaktadır. Daha geniş örneklem hacmiyle tüm dağıtım şirketleri için benzer bir çalışma maliyetleri nedeniyle proje olarak ele alınmasının daha doğru olacağı değerlendirilmektedir. 


\section{Eskişehir Osmangazi Üniversitesi IïB Dergisi}

\section{Kaynaklar}

Anderson, Eugene W.; Fornell, Claes (2000), “Foundations of the American Customer Satisfaction Index”, Total Quality Management, Vol.11 No.7: 869-882.

Bayol, Marie-Paule; Foye, Anne de la; Tellier, Carole; Tenenhaus, Michel (2000), "Use of PLS path modelling to estimate the European Consumer Satisfaction Index (ECSI) model", Statistica Applicata, Vol.12 No.3: 361-375.

Barsky, Jonathan D. (1992), "Customer satisfaction in the hotel industry: meaning and measurement", Journal of Hospitality and Tourism Research, Vol.16 No.1: 51-73.

CFI Group (2013), "The American Customer Satisfaction Index (ACSI) Technology: A Methodological Primer".

Cassel, Claes-M. (2001), "Measuring Customer Satisfaction in the Public Sector." https://www.scb.se/Grupp/Produkter_Tjanster/Kurser/Tidigare_kurser/q2001/Session_29.pdf.

Deng, Wei Jaw; Yeh, Minglang; Sung, Mialang (2013), “A customer satisfaction index model for international tourist hotels: Integrating consumption emotions into the American Customer Satisfaction Index", International Journal of Hospitality Management, Vol.35: 133-140.

Eskildsen, Jakob; Kristensen, Kai; Juhl, Hans JØrn; Ostergaard, Peder (2004), "The Drivers of Customer Satisfaction and Loyalty: The Case of Denmark 2000-2002", Total Quality Management, Vol.15 No.5-6: 859-868.

Fornell, Claes; Lacker, David F. Larcker (1981), "Evaluating structural equation models with unobservable variables and measurement error", Journal of Marketing Research, Vol.18: 39-50.

Fornell, Claes; Bookstein, Fred L. (1982), "Two structural equation models: LISREL and PLS applied to consumer exitvoice theory", Journal of Marketing Research, Vol.19 No.4:440-452.

Fornell, Claes (1992), "A national customer satisfaction barometer: the Swedish experience", Journal of Marketing, Vol.56 No.1: 6-21.

Fornell, Claes; Cha, Jaesung (1994), Partial least squares, In R. Bagozzi (Ed.), Advanced methods of marketing, 52-78. Cambridge: Blackwell.

Fornell, Claes; Johnson, Michael; Anderson, Eugene W.; Cha, Jeasung; Bryant, Barbara Everitt (1996), "The American Customer Satisfaction Index: Nature, Purpose, and Findings", Journal of Marketing, Vol. 60 No.4: 7-18.

Dülgeroğlu, İsmail (2017), “Son Tüketicilerin Değer Bilinci ve Fiyat-Kalite İlişkilerinin İnternet Üzerinden Satın Alma Davranışı Üzerindeki Etkisi: Kırklareli İlinde Bir Araştırma”, Kırklareli Üniversitesi İktisadi ve Idari Bilimler Fakültesi Dergisi, Vol.6 No.1: 53-63.

Grigaliūnaitè, Viktorija; Pilelienè, Lina (2013), “Customer Satisfaction With Catering Services In Lithunia”, Regional Formation and Development Studies, Vol.3 No.11:75-87.

Hair, Joseph F.; Tatham, Ronald L., Anderson, Rolph E.; Black, William (1998), Multivariate data analysis with readings, 5th Edn. Englewood Cliffs, NJ: Prentice Hall.

Hair, Joseph F.; Ringle, C. M., and Sarstedt, M. (2011). PLS-SEM: Indeed a silver bullet. The Journal of Marketing Theory and Practice, Vol.19 No.2:139-152.

Hair, Joseph F.; Hult, G. Tomas M.; Ringle, Christian M.; Sarstedt, Marko (2013), A primer on partial least squares structural equation modeling (PLS-SEM), SAGE Publications, Inc.

Hirschman, Albert O. (1970), Exit, Voice, and Loyalty: Responses to Declines in Firms, Organizations and States, Harvard University Press, Cambridge, MA.

Jacoby, Jacob (1971), "A Model Of Multi-Brand Loyalty”, Journal of Advertising Research, Vol.11: 25-30.

Johnson, Michael; Gustafsson, Anders; Andreassen, Tor Wallin; Lervik, Line; Cha, Jaesung (2001), "The Evaluation and Future of National Customer Satsifaction Index Models", Journal of Economic Psychology, Vol.22 No.2: 217-245.

Kandampully, Jay; Suhartanto, Dwi (2000), "Customer loyalty in the hotel industry: the role of customer satisfaction and image", International Journal of Contemporary Hospitality Management, Vol.12 No.6: 346-351.

Kline, Rex B. (2011), Principles And Practice Of Structural Equation Modeling, New York: Guilford Press.

Knutson, Bonnie J. (1988), "Frequent travelers: making them happy and bringing them back", The Cornell Hotel and Restaurant Administration Quarterly, Vol.29 No.1: 83-87.

Lee, Yu-Cheng; Wang, Yu-Che; Lu, Shu-Chiung; Hsieh, Yi-Fang; Chien, Chih-Hung; Tsai, Sang-Bing; Dong, Weiwei (2016), "An Empirical Research on Customer Satisfaction Study: A Consideration Of Different Levels of Performance", SpringerPlus, Vol.5 No.1:1577. doi:10.1186/s40064-016-3208-z. 
Lohmöller, Jan-Bernd (1984), LVPLS 1.6 program manual: latent variables path analysis with partial least-squares estimation; mit 2 Disketten Version 1.8, Köln: Zentralarchiv für Empirische Sozialforschung.

Lohmöller, Jan-Bernd (1989), Latent Variable Path Modeling with Partial Least Squares, Physica, Heidelberg.

Maxham, James G.; Netemeyer, Richard G. (2002), “Modeling customer perceptions of complaint handling over time: the effects of perceived justice on satisfaction and intent", Journal of Retailing, Vol.78 No.4: 239-252.

Mutua, John; Ngui, Diana; Osiolo, Helen; Aligula, Eric; Gachanja, James (2012), "Consumer satisfaction in the energy sector in Kenya", Energy Policy, Vol.48: 702-710.

Satria, Rd. Okky; Suzanto, Boy; Sidharta, Iwan (2015), "The Role of Customer Satisfaction and Loyalty though Student Perception on Mobile Broadband Based on Consumer Satisfaction Index Model (CSI)", International Journal of Business Quantitative Economics and Applied Management Research, Vol.2 No.5: 56-71.

Pilelienè, Lina; Almeida, Nuno; Grigaliūnaitè, Viktorija (2016), “Customer satisfaction in catering industry: Contrasts between Lithuania and Portugal", Tourism\&Management Studies, Vol.12 No.1: 53-59.

Schneeweiss, Hans (1991), Models with latent variables: LISREL versus PLS, Statistica Neerlandica, Vol.45 No.2:145157.

Smith, Amy K.; Bolton, Ruth N. (1998), "An experimental investigation of customer reactions to service failure and recovery encounters: paradox or peril?", Journal of Service Research, Vol.1 No.1: 65-81.

Song, Haiyan; Li, Gang; Veen, Robert van der; Chen, Jason Li (2011), “Assessing Mainland Chinese Tourists' Satisfaction with Hong Kong Using Tourist Satisfaction Index", International Journal of Tourism Research, Vol.13 No.1: 82-96.

Strenitzerová, Mariana; Gan̆a, Ján (2018), “Customer Satisfaction and Loyalty as a Part of Customer-Based Corporate Sustainability in the Sektor of Mobile Communications Services", Sustainability, Vol.10: 1657. doi:10.3390/su10051657.

Sugiati, Tinik; Thoyib, Armanu; Hadiwidjoyo, Djumilah; Setiawan, Margono (2013), "The Role of Customer Value on Satisfaction and Loyalty (Study on Hypermart's Customers)", International Journal of Business and Management Invention, Vol.2 No.6: 65-70.

Tunçay, Ahmet (2009), “Müşteri memnuniyeti algısı temel alınarak EFQM mükemmelik modeli ile kurumsal performans ölçümü: bir lojistik firma uygulaması", Yüksek Lisans Tezi. Kara Harp Okulu. Savunma Bilimleri Enstitüsü. Malzeme Tedarik ve Lojistik Yönetimi Ana Bilim Dalı.

Tenenhaus, Michel (1998), La Régression PLS: théorie et pratique, Technip, Paris.

Tenenhaus, Michel (1999), "Lapproche PLS. Revue de Statistique Applique”, Vol.47 No.2: 5-40.

Tenenhaus, Michel; Vinzi, Vincenzo Esposito; Chatelin, Yves-Marie; Lauro, Carlo (2005), "PLS path modeling”, Computational Statistics \& Data Analysis, Vol.48 No.1:159-205.

Terblanche, Nic S. (2005), "A Study of Two Customer Retention Measures: The American Customer Satisfaction Index And The Conversion Model", ANZMAC Conference: Relationship Marketing (Consumer), Vol 1:50 - 65.

Tüzüntürk, Selim; Dülgeroğlu, İsmail; Gönüller, Şeref (2016), “Avrupa Müşteri Memnuniyeti Endeksi Modeli: Marmara Bölgesi'nde Bir Lüks Otomobil Markasının Satış Sonrası Hizmetlerinin Bulguları", Akademik Bakış Uluslararası Hakemli Sosyal Bilimler Dergisi, Vol 55: 109-131.

Wetzels, M., Odekerken-Schroder, G., \& van Oppen, C. (2009), “Using PLS path modeling for assessing hierarchical construct models: Guidelines and empirical illustration", MIS Quarterly, Vol.3No.1: 177-196.

Wold, Herman. (1982), Soft modeling: The basic design and some extensions, In Jöreskog, K. G. And Wold, H., editors, Systems Under Indirect Observations: Part I, 1-54. North-Holland, Amsterdam.

Wold, Svante; Martens, Herald; Wold, Herman (1983), The multivariate calibration problem in chemistry solved by the PLS method, In In: Ruhe, A., Kagstrom, B. (Eds.), Proceedings of the Conference on Matrix Pencils. Lectures Notes in Mathematics, Heidelberg. Springer.

Wold, Herman (1985), Partial least squares, In S. Kotz, and N. L. Johnson, (Eds.), Encyclopedia of Statistical Sciences, 6:581-591. New York: Wiley.

Van Ryzin, Gregg G.; Muzzio, Douglas; Immerwahr, Stephen; Gulick, Lisa; Martinez, Eve (2004), "Drivers and Consequences of Citizen Satisfaction: An Application of the American Customer Satisfaction Index Model to New York City", Public Administration Review, Vol.64 No.3:331-341.

Vinzi, Vincenzo Esposito; Trinchera, Laura; Amato, Silvano (2010), PLS path modeling: from foundations to recent developments and open issues for model assessment and improvement, In: V.E. Vinzi, W.W. Chin, J. Hensler, and H. Wold (Eds.,) Handbook of partial least squares. Heidelberg: Springer. 


\section{Eskişehir Osmangazi Üniversitesi IïBF Dergisi}

Zeithaml, Valarie A.; Berry, Leonard L.; Parasuraman, Ananthanarayanan (1996), "The behavioral consequences of service quality", Journal of Marketing, Vol.60: 31-46.

https://www.smartpls.com/documentation/algorithms-and-techniques/model-fit-16-12-2019. 


\section{Extended Summary \\ Investigation of the Quality of Service of An Electrical Distribution Company with Partial Least Squares Structural Equation Modeling}

The establishment and development of competitive conditions for the Electricity Distribution Companies (EDC) responsible for the maintenance, repair and operation of the city distribution networks are being evaluated. According to the latest regulations of the electricity market, subscribers will be able to receive services from electricity distribution companies that offer high service quality. In this way, competition conditions in the electricity market will increase, and distribution companies will have to make more efforts to make their service quality customer-oriented. Furthermore, it is thought that the Ministry of Energy and Natural Resources can follow the services of these distribution companies by developing various indices through measurable models related to service quality satisfaction. In this study, the service quality of the customers of an electricity distribution company was investigated with the American Customer Satisfaction Index (ACSI) Model. The factors included in the ACSI model are Perceived Quality, Perceived Value, Customer Complaints, Customer Expectations and Customer Loyalty. In this study, the relationships between the factors and the ACSI model were tested with the help of Partial Least Squares Structural Equation Modeling (PLSSEM).

ACSI is used both to measure the satisfaction of customers using products and services in the market and to compare the measured sectors within each other. One of the most important characteristics of ACSI is that it is based on a satisfaction assessment of cumulative quality rather than the latest experience of customers.

The hypotheses tested in the study are summarized below;

H1: Perceived value has a positive effect on customer satisfaction.

$\mathrm{H} 2$ : The perceived quality has a positive effect on the perceived value.

H3: Perceived quality has a positive impact on customer satisfaction.

$\mathrm{H} 4$ : Expectation has a positive effect on the perceived value.

$\mathrm{H} 5$ : Expectation has a positive effect on perceived quality.

H6: Expectation has a positive effect on satisfaction.

H7: Satisfaction has a positive effect on loyalty.

H8: Satisfaction has a positive effect on the complaint.

H9: The complaint has a positive effect on loyalty.

Mutua et al (2012) was used in the design of the data collection tool. The data collection tool demographic information used in the study is divided into 3 sections to measure the service quality and customer satisfaction of the Electricity Distribution Company. Demography section includes information such as gender, age, average monthly electricity bill of the person completing the survey. In the second part, the expressions regarding the attitude were as follows: 1- I strongly disagree, 10- I totally agree, and in the third part, the expressions used for the evaluation of the services provided by the Electricity Distribution Company were 1- Very Low, 10- Very High. The survey was conducted face to face with 400 people between 30.11.2018 and 27.12.2018 in Eskişehir Büyükdere Neighborhood where all social strata lived. In the data collection tool, customer satisfaction, loyalty, customer complaint, perceived value, perceived quality and customer expectations factors are included in the proposed model. In order to determine the reliability of the data collection tool and whether the questions were understandable, the questionnaire was piloted to 100 people. In the analysis results, Cronbach's alpha $(\alpha)$ coefficient was calculated as 0.96 and internal consistency of the data collection tool was evaluated as sufficient.

In this study, the attitudes towards the service measurement of an electricity distribution company were analyzed by using the ACSI model using the Partial Least Squares Structural Equation Modeling (PLS-SEM) method. PLS-SEM is a statistical approach used to model the multivariate complex relationships between observed and latent variables. PLSSEM is a component-based approach in which the concept of causality is formulated in a linear manner. PLS-SEM is seen as a soft modeling technique when compared with other statistical analyzes. That is to say, it is easy to form a model with PLS-SEM in cases where it is difficult or impossible to meet the assumptions (assumptions related to normal distribution) required in multivariate statistics. In addition, good results are obtained with PLS-SEM although there is missing data when the sample is large enough.

According to the results of the study, a statistically significant relationship was found between the expectation external latent variable and perceived quality internal latent variable. This result means that the perceived quality level of the distribution company increases as the expectations of the subscribers are supplied. There was a statistically 


\section{Eskişehir Osmangazi Üniversitesi IïBF Dergisi}

significant correlation between the expected external latent variable and the perceived value of the internal latent variable. This finding means that as long as the expectations of the subscribers are supplied, there will be a balance between the fees paid for the services and the quality of the perceived services. A positive statistically significant relationship was found between the expectation external secret variable and the satisfaction internal secret variable. In other words, the satisfaction level of the electricity distribution company increased as the expectations of the subscribers are supplied. A statistically significant correlation was found between perceived quality and perceived value. That is, if the subscribers meet the needs of the service they receive and feel confident, their evaluations about the fee they pay for the service will be positive. A statistically significant correlation was found between perceived quality and satisfaction latent variable. Accordingly, it can be interpreted that the better the consumption experience, the better their satisfaction will be positively affected. A statistically significant correlation was found between perceived value and satisfaction latent variables. If the subscribers meet the needs and trust of the service they receive, their satisfaction levels will increase. A statistically significant relationship was found between satisfaction and latent variables. This finding means that as the satisfaction of the services of the electricity distribution companies increases, the beliefs of the participants that their complaints can be resolved easily will be strengthened. A statistically significant correlation was found between satisfaction and loyalty latency variables. This means that as the satisfaction of the electricity distribution companies increases their loyalty to the related company. A statistically significant relationship was found between the complaint and loyalty latency variables. This result will increase the commitment of the distribution companies to increase the beliefs of the participants that their complaints can be easily resolved.

The ACSI satisfaction score was calculated as $46 \%$ to measure the degree of satisfaction of the subscribers of the EDC. This result shows that satisfaction is below average. An enterprise focused on customer satisfaction should try to meet the expectations of the customers by making innovations in the services it offers. In this regard, in order to provide better quality services, electricity distribution companies should aim to ensure the satisfaction of their subscribers by taking into consideration their complaints and demands. In this study, service quality satisfaction index is calculated separately for all electricity distribution companies and the necessity of developing an index is evaluated. It is also recommended that this index account be calculated at least every 6 months and followed by the Ministry of Energy and Natural Resources. It should be noted that it may be beneficial to develop a competitive market by expanding the possibilities of subscribers to select electricity distribution companies from the free market. 